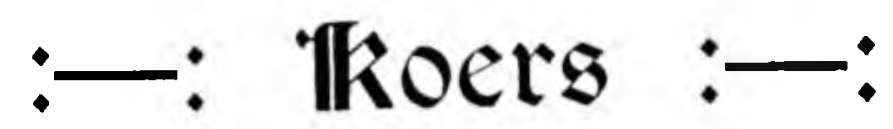

TWEEMAANDELIKSE TYDSKRIF.

\begin{tabular}{llll}
\hline DEEL XVIII. No. 4. & FEBRUARIE. & 1951.
\end{tabular}

\title{
BY ONS SELFSTANDIGWORDING.
}

Hierdie uitgawe van „Koers" staan ook in die teken van die heuglike gebeurtenis van die selfstandigwording van die P.U.K. vir C.H.O. Ons bied aan ons lesers 'n feesnummer, met artikels oor onderwerpe uit al die fakulteite wat aan die P.U. verteenwoordig is.

Dat ons inrigting tot 'n selfstandige universiteit vir Christelike hoër onderwys verhef word is 'n wonder in ons ö̈: dit is geen mensewerk nie maar 'n wilsbeskikking van ons hemelse Vader. Ons inrigting sal vanaf die datum van sy selfstandigwording met wetlike reg die karakter dra van 'n inrigting vir Christelike hoër onderwys. Die onderrig aan die inrigting sal beslis Christelik wees, en die lerare daaraan werksaam sal belydende Christene (soos wel in die verlede) moet wees en bly.

Met ons selfstandigwording as inrigting, tree ook „Koers" in 'n enigrsins nuwe stadium in. Meer as dit die geval in die verlede was word „Koers" 'n orgaan van ons inrigting: die Raad het nie alleen sy geldelike steun vergroot nie maar ook 'n verteenwoordiger op ons Direksie en Redaksie benoem. Ons is die Raad dankbaar vir sy erkenning en ondersteuning.

Mag die Potchefstroomse Universiteit vir Christelike Hoër Onderwys tot in lengte van dae getrou aan sy begin bly, en in die wetenskap alleen die cer van ons Skepper soek! In die lig van Sy geopenbaarde waarheid graan ons die groot toekoms met Christelike geloof in!

Namens Direksie en Redaksie

J. CHR. COETZEE (voorsitter). 